\title{
Problems and Solutions of Financing for New Energy Enterprises
}

\author{
Mingyun $\mathrm{Chi}^{1{ }^{1, *}}$ \\ ${ }^{1}$ College of Foreign Studies, Shandong Technology and Business University Shandong Province, China \\ *Corresponding author. Email: 532075718@qq.com
}

\begin{abstract}
Examine the obstacles faced by new energy enterprises: large demand for financing amount, long financing period, few financing opportunities for new energy enterprises, unsystematic finance of new energy enterprises, weak strength of new energy enterprises, analysis on the causes of problems existing in commercial banks in supporting the development of new energy industry. Find solutions: improve financial services and capital market, open up financing channels, build financing platform Government support and enterprises themselves to strengthen risk awareness and improve the development of commercial banks from both internal and external aspects are of great significance to the sustainable development of national new energy.
\end{abstract}

Keywords: Financing, New energy enterprises, Financial institution

\section{INTRODUCTION}

At present, new energy enterprises in emerging industries are unable to carry out project construction or product production due to financing problems. Therefore, new energy companies take the financing problems of new energy companies as research topics, investigate the financing restrictions of new energy undertakings, solve problems and seek countermeasures. It is necessary to investigate the financing difficulties of new energy enterprises in detail from the financing situation. Due to the lack of research on new energy financing, it is undoubtedly of great theoretical and practical significance to study the problem of new energy financing and find a reasonable financing strategy deeply and seriously. This paper tries to find the financing strategy for the development of new energy industry.

\section{FINANCING STATUS AND EXISTING PROBLEMS OF NEW ENERGY ENTERPRISES}

\subsection{Financing Status of New Energy Enterprises}

With the continuous development of economy and society, China's energy structure has changed from traditional fossil energy to diversified new energy, and gradually formed a clean and low-carbon energy structure. New energy is mainly concentrated in the fields of photovoltaic, wind power and other biomass energy and atomic energy. In recent years, the new energy industry has developed rapidly, and the newly added equipment capacity has increased by more than $50 \%$ every year. A considerable investment is financial leasing.

Most of them are private enterprises developing new energy, and there are difficulties in financing in China. Under the pressure of development, state-owned enterprises must focus on power, photovoltaic and major infrastructure construction. One of the reasons for the lack of subsidies is that private enterprises gradually sell the original land. However, the main problem is that some private enterprises have large financial leverage effect and high cost. Most of the bank's non-performing loans come from the new energy industry. This budget failure directly affects the bank's attitude towards new energy enterprises, and the negative impact of loans on the future development of the new energy industry is still severe.

\subsection{Financing Problems of New Energy Enterprises}

\subsubsection{The financing needs of new energy enterprises are difficult to meet today}

According to the joint prediction of the US energy consortium and China's national development and Reform Commission, by 2020, China's demand for clean technologies such as new energy, energy conservation and investment in environmental protection will be about 7 billion yuan, and the investment in new energy projects will be hundreds of millions to billions of yuan, Hai Zhenhua, deputy director of the national development and Reform Commission, suggested that the new energy 
investment in China should reach a huge amount of 41000 trillion yuan.

In view of such a huge capital demand, it is difficult to meet the development demand only through the following ways: Taking the development of new energy industry as the premise of technological innovation breakthrough is the first stage of large-scale investment and an important factor in the development of new energy projects in recent years.

\subsubsection{Lack of financing channels}

Compared with other developed countries, the development time of China's new energy companies is relatively short. Due to the imperfect market environment, the financing difficulties affect their future sustainable development. The main difficulties are as follows: first, compared with the financing channels of developed countries, the financing channels are single, only absorbing financing and bond financing, and reducing the use of industrial funds, trust funds and other channels; Secondly, domestic commercial banks prefer to invest in large companies with strong profitability and good solvency rather than invest in new energy companies, because the investment risk of new energy enterprises is very high.

\subsubsection{High financing financial risk of new energy enterprises}

New energy enterprises have different types of energy in different industries, so financial risks must be strictly controlled. The diversity of financing methods also makes different financing methods bear different financial risks and financing costs. Therefore, it is necessary to reasonably select and determine financing methods to save financing costs and reduce financing risks. In particular, the financing of new energy enterprises includes the following aspects: first, the financing scale is large. If the new energy industry has high requirements for technical objectives, it can be supported through risk management, which means that compared with traditional industries, they need a lot of $\mathrm{R} \& \mathrm{D}$ funds. Secondly, the capital period is relatively long. The risk is relatively high and the capital recovery cycle is relatively long. A large part of the capital needs to be used to support the normal operation of the enterprise for analysis and evaluation.

\subsection{4. problems encountered by commercial banks in helping the development of new energy industry}

Commercial banks pay more and more attention to the economic development of new energy enterprises. Under the correct leadership of the National Communist Party, they began to adjust loans and set up various policies to support the development of new energy industry, such as issuing green loans. However, there are still several problems in the process of banks helping enterprises: lack of corresponding information disclosure mechanism for commercial banks and lack of information access, The definition of the project is generally based on the relevant information provided by the local environmental protection department. Due to the timeliness, correctness and lag of information transmission, the project is delayed and delayed, which cannot meet the specific progress requirements of our credit application review and affect the implementation effect of green credit.

\section{ANALYSIS ON THE CAUSES OF PROBLEMS ENCOUNTERED IN FINANCING OF NEW ENERGY ENTERPRISES}

\subsection{Large Demand for Financing Amount and Long Financing Period}

According to the big data forecast by the US Energy Foundation and China's national development and Reform Commission, by 2022, China's total capital investment in clean technologies and high-tech fields such as new energy, energy conservation and environmental protection will be about 9 trillion yuan, and China needs 4.1 trillion yuan of new energy investment. In view of such huge capital demand, it is difficult to meet the development needs only by endogenous financing of new energy enterprises. At the same time, new energy enterprises will expand many new businesses, develop new products and expand the market, which requires a lot of funds. Simply expanding new business through profitability may not be enough. In addition, there is a great operational risk. If there is a problem, there will be a problem with the business previously completed by the new business company, including cash flow. Enterprises can move from prosperity to failure or even death. Therefore, some enterprises should not only carry out one round of financing, but also operate their business through several rounds of financing.

\subsection{Few Financing Opportunities for New Energy Enterprises}

The company lacks nuclear technology. When new energy companies carry out financing activities, they can use intangible assets as guarantee or guarantee. However, there is a huge gap between domestic new energy companies and foreign new energy companies in the field of technology, and they rely more on foreign technology. Energy companies generally face foreign markets and rely more on imports of raw materials. Nowadays, countries all over the world pay great attention to the research, development and utilization of new energy. Once the exporting country 
boycotts the trade policy of China's new energy products, domestic new energy enterprises will suffer heavy losses. Due to the lack of nuclear technology, domestic new energy companies do not have strong price strength or significant competitive advantage in the international market.

\subsection{The Finance of New Energy Enterprises Is Not Systematic, and Their Own Strength Is Weak}

When new energy companies get financing, some managers have high expectations for a project. Due to the lack of accurate analysis, they subjectively believe that the project will succeed and have weak risk awareness [7]. Once there are problems, they will panic: new energy enterprises have no correct positioning, no independent opinions on financing decisions, and no analysis and comprehensive consideration of possible risks, which increases the financial risk of enterprises in practice.

\subsection{Analysis on the Causes of Problems Existing in Commercial Banks in Supporting the Development of New Energy Industry}

In terms of support for commercial banks, there is a lack of relevant information disclosure mechanism and sufficient information access channels, which are usually based on the data provided by the local environmental protection department. The correctness and delay of information transmission will be continuously delayed, which can not meet the specific progress requirements of our credit application review and affect the implementation effect of green credit. In view of the potential risks of the project, the decision-making institutions and experts do not have a clear understanding of the purpose and repayment source of the project credit, resulting in a lack of predictability. At present, the national support standards for the new energy industry are not clear, there is a lack of detailed risk guidance and standard requirements, and the internal rating system and credit standards of commercial banks do not impose strict requirements on new energy enterprises, So that it is impossible to formulate relevant rules on the support of new energy enterprises. Although the credit support of commercial banks for new energy enterprises has become a key development project of the bank, the incentive mechanism has not been established, the employees are not active, and the enterprise does not understand. To promote green financing and incentive strategies for new energy undertakings and support banks, they can not effectively induce banks: new energy projects. In recent years, new energy projects have been implemented mainly through bank loans and the state's political support for corresponding business activities. Among them, commercial banks are still the most important way of business financing, and the financing confidence of new energy undertakings is insufficient.

\section{COUNTERMEASURES TO ALLEVIATE THE FINANCING DIFFICULTIES OF NEW ENERGY ENTERPRISES}

It is not easy to solve the "financing difficulty" of new energy enterprises. We need to carry out in-depth construction from many aspects, including the construction of credit guarantee, financing system, credit system, service level and service awareness of financial institutions, so as to build a set of perfect supporting facilities.

\subsection{Improving Financial Services and Capital Markets}

Considering more research, and considering that the new energy industry has conducted more research through the financial ban on the new energy industry, the new energy industry will not only show its profitability, but also increase the compensation for the opening finance of new energy companies and reduce the financing conditions of enterprises. Companies with different financing methods face different financial risks. Therefore, it is necessary to evaluate different financing methods in order to determine the best financing method. Companies may have to repay higher interest rates, which greatly increases financing costs. If the selected financing method is not guaranteed, in view of the fact that if the other party withdraws its capital suddenly, the enterprise may face disaster; Whereas, when determining the financing mode, new energy enterprises must comprehensively evaluate their own situation and adopt the most favorable financing mode for their own enterprises; In terms of financing, we should do a good job in contract management to prevent the other party from suddenly withdrawing capital and minimize the risks borne by the enterprise.

\subsection{Open up Financing Channels and Build a Financing Platform}

To obtain outstanding advantages in capital cost to compete with other enterprises, it is necessary to strengthen the universality of financing field and financial innovation. The financing difficulty of new energy enterprises has been a problem that has plagued the public for a long time. How to solve this problem is an important task in front of us, which not only needs the efforts of the company itself, It also needs effective cooperation with external factors. In this regard, relevant enterprises of financial institutions have achieved good results in innovation. Financial innovation can expand the scope of enterprise activities to a certain extent and solve financing problems. Industry and finance can achieve a win-win situation. In addition, with the growth and maturity of new energy projects, the proportion of social capital and bank finance can be gradually increased. Earnings are higher than banks. Banks only participate as priority funds, which will greatly reduce 
credit risk and increase profits. They will be ready. At the same time, banks can also innovate financial products and service modes according to the characteristics of new energy undertakings, and innovate characteristic financial service systems according to the characteristics of new energy equipment manufacturers and manufacturers, including accounts receivable management, introduction of online credit cards Cash management and other services].

\subsection{Government Support and Enterprises Themselves to Strengthen Risk Awareness}

To some extent, vigorously developing new energy industry can alleviate the problems of environmental pollution and resource shortage. Therefore, the government should pay more attention to the healthy development of new energy enterprises, actively implement practical strategies that can effectively promote the development of new energy enterprises, provide more help for the development of new energy enterprises, and create a larger platform and more space for the development of new energy enterprises. Formulate and implement relevant preferential policies and legislative and administrative provisions in all aspects, and provide legal support for the financing of new energy projects. First, the government should actively improve financing channels, provide funds for new energy enterprises and reduce financial losses caused by insufficient policy financing channels. This requires a lot of money. However, the development of new energy industry still lacks perfect market scale and financing difficulties. It can be seen that the government must support new energy projects from the perspective of financing. First, formulate relevant laws and regulations to ensure their implementation in many aspects; Second, we should actively perform its functions; Continuously improve financing channels, actively develop diversified financing methods, avoid the negative impact of imperfect government policies on new energy project financing, and support power enterprises to adopt various new financing methods.

\subsection{Improving the Development of Commercial Banks from both Internal and External Aspects}

Internally, we should reform the credit decision-making mechanism, enhance the ability of banks to carry out risk management, timely and carefully study the changes of national environmental policies and preferential policies for new energy enterprises, timely adjust the credit strategy, absorb the advanced international experience, and then combine the practical experience, Establish a complete and comprehensive new mechanism for energy credit risk prevention and control of commercial banks, do a good job in Fengqian research, evaluation and evaluation, constantly monitor the development of enterprises after each process of lending and repayment, strengthen the risk management ability of new loans in the energy industry, strengthen financing innovation, and make use of the capital market conditions at home and abroad, Then it can provide new energy enterprises with financing needs, investment management and asset management services; Social responsibility funds and industrial funds can also be established to provide timely financial support for all new energy enterprises in the whole society. Finally, it will play an active role in saving energy and resources, protecting the environment and fulfilling corporate citizenship responsibilities.

\section{CONCLUSION}

At present, the development of new energy enterprises is still in its infancy. Financing risk is a major problem that new energy enterprises need to solve. Stabilize the competition among enterprises in the external market and explore new markets; Only by deeply understanding the financial situation of the new energy industry, analyzing financial risks and studying effective control measures can we firmly grasp the control right of financial risks, implement effective strategies to avoid risks, make rational use of the internal funds and financing funds of the enterprise, and try to create maximum economic benefits for the enterprise, At the same time, adjust the relationship between enterprises and the government. In short, in the process of financing the new energy industry, we should fully respect the role of market mechanism in capital allocation, and market forces should effectively manage the capital allocation of strategic emerging industries in the early stage of development and the sustainable development in the later stage, so as to realize the healthy development of new energy enterprises.

\section{REFERENCES}

[1] Analysis on financing development status of new energy industry. China finance and Economics Press, April 2021

[2] Financial Accounting Standards Board statement Accounting Standards No. 13 - lease accounting, January 2021

[3] IAS 17, lease accounting, 2021.09

[4] Shao Cuili. New ideas on accounting treatment of financial leasing under the new accounting standards $[\mathrm{J}]$ Zhengzhou: China's management informatization, June 2021

[5] Hennessy and Raman. An Empirical Study. The Journal of Finance[J],2019.09.

[6] Zhu Xiping, Chen Ying. On the reform of investment and financing system in the process of China's new energy development and construction [J]. Financial, political and legal information, January 2020 